\title{
ГНОСЕОЛОГІЯ
}

\author{
UDC $101.1+165+167 / 168$ \\ DOI https://doi.org/10.24195/spj2310-2896.2019.4.2
}

Borinstein Yevgen Ruslavovich

Doctor of Philosophical Sciences, Professor,

Head of Department of Philosophy,

Sociology and Management of Sociocultural Activities State Institution "South Ukrainian National Pedagogical University named after K. D. Ushynsky"

26, Staroportofrankivska str., Odesa, Ukraine

Konakh Mikola Semyonovich

Doctor of Philosophical Sciences, Professor,

Teacher

Kamensk Medical College

7, Medychna str., Kamianske, Dnipropetrovsk region, Ukraine

\section{THE ESSENCE AND GENESIS OF SCIENTIFIC KNOWLEDGE: PHILOSOPHICAL PROBLEMS}

The article examines the essence and Genesis of scientific knowledge from the point of view of philosophy. The role of activity in scientific knowledge is analyzed. At the same time, science is defined as the sphere of human spiritual activity aimed at obtaining, substantiating and systematizing interactive knowledge about the world. A historical digression into the development of science is made. We are talking about scientific knowledge, which includes: regularities of scientific and cognitive activity, the main principles of science; features of the origin and historical development of science; the specifics of the existence of science as a social institution; structure, dynamics, levels and forms of scientific knowledge, means and methods of achieving this knowledge; the significance and prospects of science in the modern world. The authors consider the features of modern scientific knowledge, which is understood as a strong information capacity and its size super-complex flexible structure consisting of various scientific disciplines, fields of knowledge, levels, types and forms of scientific knowledge that are based on scientific activity. The authors note the main philosophical and methodological approaches to the definition of science, namely, the logical and epistemological approach; positivist approach; sociological and cultural approaches. For the authors, it is a fundamental distinction between epistemology, which analyzes the place of knowledge in modern reality, and epistemology, which studies the cognitive process as a whole. The authors consider the important role of objective knowledge, which can only be given, in their view, by a systematic philosophical worldview.

Key words: science, knowledge, scientific knowledge, modern scientific knowledge, everyday knowledge, epistemology, epistemology, positivism.

The concept of science is used and studied by various disciplines - philosophy, history, sociology, and cultural studies. Accordingly there are different approaches to the definition of this concept, however, in our opinion, the most logical is the understanding of science as a specific activity of people. In order to emphasize the systematic nature of scientific activity, we can summarize: science is a system of knowledge about the laws of nature, society, and thinking, which is based on the specific activities of people associated with the development and systematization of theoretical objective knowledge about reality. We fully agree with scientists who consider activity as "a Specific form of human attitude to the world around us and to oneself, which is expressed in the expedient change and transformation of the world and human consciousness" [1, p. 70]. 
Therefore, any activity:

- has a goal;

- leads to the final result;

- provides methods and means of obtaining it;

- it is directed at certain objects, revealing its subject in them;

- characterized by the actions of subjects who, in solving their tasks, enter into certain social relations and form various forms of social institutions.

In all these dimensions, science differs significantly from other spheres of human activity (Economics, politics, art). According to all the above features, science can also be defined as the sphere of human spiritual activity aimed at obtaining, substantiating and systematizing interactive knowledge about the world. Science is formed by such components as knowledge (scientific knowledge), the corresponding activity (scientific method), and social forms of its organization (scientific society).

The existence of science can be defined in three main aspects:

- science as the generation of new knowledge;

- science as a social institution;

- science as a special sphere of culture.

First of all, science is a specific production and systematization of knowledge about the laws of the world by means of theoretical justification and empirical testing and verification of cognitive results in order to reveal their objective content (truth, reliability, and interactivity). These tools provide various options for using theories, concepts, mathematical extrapolations, deductive structures, observational data, experiments, inductive conclusions, experience as such, or the combined application of these forms of research. Due to the specifics of these tools, new scientific knowledge is created.

Science appears to be the sphere of activity of professional scientists. The common goal that unites scientists is the search for truth. The activity of the scientific community allows us to characterize science as a social institution with certain goals, principles, norms, interests, a variety of resources and tools, a special code of scientific correctness, a specific language and means of communication.

Finally, science is a special sphere of culture. In Modern times it is science it opens the way for humanity to knowledge that is not legitimized by God, which was impossible during the middle Ages, under the rule of the religious worldview. The result of this turn is a combination of scientific theory with the practice of empirical research. The further progress of science appears to be inextricably linked with the development of technology. Scientific and technical progress givesthe ability of a person not only to gain knowledge about existing objects of the world, but also to transform the world and, accordingly, to comprehend the possibilities and consequences of these objects transformations. Thus, science provides humanity with the opportunity to learn not only the world of nature, but also the world of culture - the "second nature".

So, scientists note that "scientific knowledge is an object type of knowledge that meets the following criteria: proof, certainty, verifiability, consistency, reflexivity, usefulness, openness to criticism, methodology, ability to change and improve" [2].

But this is a classic traditional understanding. Modernity also makes its own adjustments. Therefore, we understand modern scientific knowledge as an impressive information capacity and its size supercomplex flexible structure consisting of various scientific disciplines, fields of knowledge, levels, types and forms of scientific knowledge that are based on scientific activity.

The product of scientific activity is, first of all, knowledge. In modern philosophy, knowledge is defined as a rationally based belief (proven, confirmed by experience, practice, etc.). Knowledge is always culturally and historically conditioned. Its understanding in the philosophical discourse is determined by the main task that philosophers have always solved: to understand the relationship "Man - World". The world is what is real, what actually exists. And knowledge appears as a way of connecting a person with the world, it informs a person about reality.

It is important to keep in mind that knowledge is obtained not only in science. There is scientific and non-scientific knowledge. Thus, in particular, everyday knowledge, based on common sense and human experience, deals with changing things, phenomena perceived by the senses. 
Everyday knowledge can be represented in images, representations, and skills. The diversity of vital and practical individual experience is a unique asset of people, a component of human knowledge and practice. However, the human does not reveal the whole essence of things, it has fragmentary character, is limited. Therefore, knowledge obtained with the help of the senses and generalized, can not be probable.

However, it is worth paying attention to the reservation of G. Spencer, who emphasizes: there are a priori reasons to question the truth of any philosophy of science, based on the General opinion about the distinction between scientific and everyday knowledge, without paying attention to the subordination of one to the other, without studying the reasons for the differences between these forms of knowledge [3, p. 493]. Therefore, scientific thinking is one of the ways of knowing reality that exists in parallel with others (everyday, artistic and imaginative) and cannot displace them. Different ways of thinking do not just coexist, but interact with each other, conduct a constant dialogue and can change as a result of such a dialogue. However, at every stage of the historical development of science, we are dealing with certain, certain scientific knowledge, which creates the basis for the search for new knowledge.

Therefore, scientific knowledge covers:

- regularities of scientific and cognitive activity, the main principles of science;

- features of the origin and historical development of science;

- the specifics of the existence of science as a social institution;

- structure, dynamics, levels and forms of scientific knowledge;

- means and methods of achieving this knowledge;

- the significance and prospects of science in the modern world.

But the understanding of these features can only be done with the help of philosophical problems, which give scientific knowledge a systematic character.

The philosophical direction of scientific knowledge analyzes the General characteristics of scientific activity. Therefore, the subject of the philosophical direction of scientific knowledge is the General laws and trends of scientific knowledge, methods of formation, structure and dynamics of scientific knowledge. And in modern times the philosophical direction of scientific knowledge is also engaged in research and design of methods of scientific and cognitive activity, focusing on the maximum approximation to the actual practice of scientific activity, to find out constructive ways of action to build scientific knowledge.

The attention of researchers is drawn to a number of important problems of philosophical problems of scientific knowledge. These include, in particular, questions about:

- what enables science to learn the truth and what exactly;

- what constitutes truth in scientific knowledge?;

- what is the specificity of scientific knowledge?;

- how does scientific knowledge combine analysis and synthesis, induction and deduction, theory, and experience?;

- what role do hypotheses play in science?;

- how should the concept of scientific theory be interpreted?;

- how do scientific discoveries occur?;

- what determines the content of scientific progress and revolutions?

The search for answers to the outlined questions involves researchers to the methodological principles of scientific knowledge, requires reflection, which includes science to the key categories of philosophical thought. Systematization of such searches allows us to identify several main philosophical and methodological approaches to the definition of science:

- logical-epistemological approach;

- positivist approach;

- sociological and cultural approaches.

According to the point of view of scientists-philosophers, epistemology (from the greek words episteme - "knowledge" and logos - "teaching") it is interpreted as "a section of philosophy that considers the problems of knowledge, the relation of knowledge to reality" [4, p. 286]. 
Therefore, epistemology does not cover all cognitive problems. In contrast to gnoseology (from the greek gnosis - "knowledge" and logos - "teaching"), aimed at the study of the cognitive process in General and understand as "a philosophical discipline that deals with research, criticism, and theories of knowledge" [5, p. 243], epistemology seeks to identify the foundations of knowledge about reality and the conditions of truth. It can be argued that it is a "strict epistemology" that prepares the cognitive process from the point of view of obtaining real true knowledge. Therefore, the task of epistemology is to discover the fundamental principles of scientific knowledge through logical analysis.

As a theory of knowledge epistemology was an integral part of each a philosophical concept from the beginning of the existence of philosophy. However, only in the XVII century, when science began to turn into an increasingly significant social phenomenon, there is a certain transformation of philosophical knowledge: if earlier it was dominated by ontological problems, now the main place is given to the problems of knowledge. The classic expression of R. Descartes "I think - so I exist" testifies to the assertion in European philosophy of the idea of self-evidence of consciousness, centered in the "I" of the subject of knowledge.

The problem of substantiating scientific knowledge becomes Central in the Western European philosophy of Modern times, starting with the works of F. Bacon and R. Descartes. This is due to the transition from a traditional to an industrial society, with the emergence of a free individual who relies only on himself. Accordingly, the philosophical understanding of scientific achievements, which is becoming an increasingly significant social phenomenon, becomes relevant. It is at this time that the so-called "epistemological turn" occurs in philosophy, connected with the search for an answer to the question: what exactly can be considered a sufficient justification for knowledge? This problem is at the center of philosophical discussions of the XVII - XVIII centuries. The theory of knowledge in Modern times appears primarily as a critique of metaphysical systems and traditional knowledge from the point of view of a new ideal of knowledge.

Epistemological objectivity is defined as the adequacy of knowledge of reality. The thesis that scientific knowledge can produce objective knowledge, in turn, assumes that it has and operates criteria that are based on the basis of which it is possible to judge whether a scientific theory is (relatively) true or false.

Classical epistemology is characterized by a number of features:

- hypercriticism (skeptical attitude of the external world relative to the human consciousness, the possibility of its knowledge, as well as knowledge of the consciousness of other people);

- fundamentalism (the idea that there are certain unchangeable norms that allow us to distinguish and justify knowledge);

- sub-ectocentrism (the statement of absolute reliability of knowledge about the subject's States of consciousness and unreliability of other knowledge);

- neurozentrum (the view that only scientific knowledge is knowledge in every sense).

The dominance of empiricism in natural science in the late XVIII - early XIX centuries led to the emergence of hopes that the functions of theoretical generalization of scientific knowledge can be adopted by philosophy. However, such a generalization, carried out, in particular, in the grandiose natural philosophy system

G. Hegel, caused scientists not only skepticism, but also a strong rejection. Thus, G. Helmholtz believed that natural philosophy is completely unnecessary for researchers of nature, since it is meaningless [6, p. 236]. Until the second half of the XIX century, the interaction of philosophy and scientific knowledge was not sufficiently systematic.

Most scientists in the second half of the XIX century, following the tradition, tried to interpret all scientific problems, based on the fact that science can reflect the deep properties of being. This understanding of the essence of science, rooted in the depths of history, was supported by the success of the development of physics based on mechanics. The idea that any phenomena of reality are processes that occur in space and time, which they are causally determined, are subject to a small number of laws, on the basis of which they can be accurately described, has become stronger. The mechanistic style of thinking was not unique to physicists (G. Helmholtz, G. Hertz), but also 
biologists (C. Darwin), economists (J. S. ill), historians (F. Guizot). At the end of the XIX century. mechanists called all scientists who considered science as a reflection of the essential properties of the objective world. They saw the task of scientific knowledge in explaining any phenomenon based on the assumption of its existence in space and time, as the result of the interaction of certain causes. However, understanding all the achievements of science has faced serious difficulties. The rapid growth of theoretical ideas, the expansion of means and methods of scientific knowledge made it impossible to build a consistent scientific picture of the world on purely mechanical principles.

In these conditions, the philosophy of positivism becomes widespread. Foundation the philosophy of positive (concrete-scientific) knowledge is laid down by the French thinker A. Comte, who put forward the idea of depriving philosophical knowledge of abstract speculation. The scientist argued that each science is its own philosophy, so metaphysics (classical philosophy) as the doctrine of the essence and causes of phenomena should be eliminated, and its place should be taken by "positive philosophy".

Positivists rejected the classical philosophical tradition that interpreted scientific knowledge as a reflection of the properties of the objective world. According to A. Comte, philosophy as metaphysics could have a positive impact on the development of ideas about the world only during the childhood of science, when it was metaphysical systems that performed the functions of scientific theory [7]. However, in Modern times, the theological view of the world, the highest stage of development of which A. Comte considered classical philosophy, should be completely replaced by purely scientific positive theories based on direct observation and experience. It is only necessary to understand the essence of science correctly, the positivists believed, and all metaphysical problems will be solved.

Positivism tried to "save" rationality by taking it out of science. Positive rationality consists in the study of "useful" laws that are deduced from observations that become the basis of predictions that are possible based on constant relationships between phenomena. Reality, reliability, accuracy, utility are the main characteristics of positive rationality as a philosophical thinking. The manifestations of the positivist tradition in the understanding of science are the emphasis on the ambivalent role of observation in scientific research, the recognition of hypothesis as a powerful tool of scientific search, and the description of reality as the goal of research. At the same time positivists denied qualitative changes in the scientific world knowledge, considering that the laws of science are constant and unchangeable. The call to consider science beyond philosophy and culture narrowed the horizons of scientific search, making it impossible to determine its socio-cultural significance.

At the turn of the XIX - XX centuries, the direction of "second positivism", or empiriocriticism, was formed in scientific knowledge. Its content consisted of the problems of substantiating scientific abstractions, concepts, principles, and their correlation with reality. Theorists of empiriocriticism E. Mach, R. Avenarius believed that these problems will be solved if metaphysical judgments are consistently withdrawn from science: both theoretical knowledge and scientific (empirical) experience must be freed from them, which must be subjected to consistent criticism for being "burdened" with metaphysical heritage.

Therefore, the idea reigns that science itself is able to solve any reasonably posed problems. In particular, the philosophy of science of P. Dugem has a positivist character, which contrasts the physical theory built on the daily practice of science with a logical system based on reflections hostile to concrete facts of reality [8, p. 245]. The thinker comes to the conclusion that it is impossible to deduce the elements necessary for building a scientific theory from a metaphysical system. Working at the level of phenomena, the scientist, according to P. dugem, cannot go beyond them in principle.

So, according to the proponents of "second positivism", the real knowledge is concrete facts and empirical laws. Scientific theories provide only a systematization of these facts and patterns, gradually becoming all the more perfect. A scientist does not need philosophical knowledge: awareness of the main results of scientific research, professional knowledge of special methods, a sense of common sense - these qualities are quite enough for him.

Discussions around these statements have revealed vulnerabilities in the positivist interpretation of the philosophy and methodology of science. In the XX century, the positivism 
of A. Comte, the empirio-criticism of E. Mach, R.Avenarius, and P. Dugem were sharply criticized for the phenomenalistic interpretation of science, which, contrary to the statements of its authors, was not at all free from metaphysical arguments. The development of science itself led to the defeat of phenomenalism: the discovery of the world of atoms and elementary fractions could no longer be denied. Generalizations that go far beyond the observable have spread in science: theoretical ideas are now beginning to guide experiment and observation.

At the same time, in the context of the rapid development of science in the XX century, a number of ideas of positivism were reinterpreted and developed. According to the neo-positivists, their predecessors determined the right direction in the critique of philosophy, in the elucidation of nature of science, but could not go down this path energetically and consistently. The situation has changed radically as a result of the development of logic. In particular, the works of B.Russell were aimed at clarifying the logical structure of the language of science by means of mathematical logic. The researcher divided all statements into atomic (those that fix the properties and relationships inherent in real objects) and molecular (those that indirectly describe reality; their truth can be justified by reducing them to atomic).

We can say that the works of B. Russell, A. Whitehead, G. Frege, L.Wittgenstein, M. Schlick, R. Carnap, O. Neurath laid the foundations of the "third positivism" - neopositivism (logical positivism). Within this direction, the philosophy and methodology of science becomes the subject of special study.

The most important feature of the interpretation of philosophy by representatives of logical positivism is the emphasis on its scientific character. But how is this possible if philosophy cannot be a science? It turns out that there is nothing contradictory in this requirement. G. Karnap notes that philosophizing is carried out in close connection with empirical science [9, p.128]. Neo-positivists do not recognize philosophy as a special field of knowledge, located alongside or above empirical science. Therefore, the main method of philosophizing for non-positivists is logic.

Logical analysis of science concepts has two functions:

- eliminate meaningless concepts from scientific usage, eliminate pseudo-problems, and prevent the spread of various modifications of metaphysical thinking and its products in science;

- find out the logical structure of scientific theories, using their axiomatization to reveal the real empirical content of concepts and methods used in science, explain the actual scientific statements.

The need for these functions arises from the fact that scientific activity is a natural process characterized by both the manifestation of various kinds of accidents within the science itself, and the action of various external factors on it. For example, a scientist makes extensive use of everyday language, which includes a significant component of uncertainty. His activity always has a certain psychological connotation. Due to various socio-historical reasons, it is burdened with the legacy of concepts and problems of traditional philosophy. Science is constantly under the influence of external religious and political interests in relation to its essence. The task of the philosopher is to identify what is inherent in science as such by its nature. And this can be achieved, according to logical positivists, only on the path of logical reconstruction of science.

The approaches of logical positivism are not widely accepted by modern scientists. In philosophical and scientific problems from the second half XX century on the historical dynamics of science, taking into account the influence of socio-cultural factors on it, is becoming widespread in the twentieth century. R.Merton notes that the subject of sociology of science in a broad sense is the dynamic interdependence between science as a constant social activity, through which cultural and civilizational products are created, and the external social structure [10, p. 76]. Through that, the influence of society on science must be investigated in the same way as the influence of science on society. It is the philosophy of science that will determine the General patterns of such influences.

Dissemination of sociological and cultural approaches to development scientific knowledge in the XX century shows the emergence of such trends as internalism and externalism. Supporters of internalism (A. Coire, J. Agassi) believe that the development of scientific ideas is inherent in its own, immanent logic, which does not depend on the influence of the social environment. To 
reconstruct the history of science, internalists consider it appropriate to focus exclusively on the analysis of scientific knowledge as an Autonomous entity. The main drawback of the internalist approach is its one-sidedness. Radical internalism characterizes the human subject of knowledge only as a "spiritual substance", the explanation of the nature of which cannot be based on material and social prerequisites. This position leads to the absolutization of differences in intellectual and cultural-historical, social aspects of the development of science, to their opposition.

The concept of externalism defines the development of science primarily as a social process. Externalists (B. M. Gessen, R. Merton, J. Bernal, A. Crombie, J. Needham) consider the influence of external social factors on the development of scientific knowledge: the needs of society, as a result of which the subject of scientific research changes, public or private funding of certain areas of science, and technological progress. Thanks to external research, new aspects, components and factors of the development of science have been clarified, and the desire to explain the historical conditionality of this development has been realized, taking into account socio-economic and cultural-historical factors. At the same time, the approach of representatives of externalism also looks straightforward and simplified. Externalists tried to deduce complex elements of science (its content, themes, methods, theories, hypotheses) directly from economic reasons, ignoring the features of science as a spiritual production, specific activities for obtaining, justifying and verifying objectively true knowledge.

The appeal to the internalist and externalist interpretations of the development of scientific knowledge is mainly of historical interest in our time. It is obvious that science cannot be considered as a phenomenon completely closed in itself or, on the contrary, completely subordinated to external economic factors. The result of discussions between internalists and externalists is the spread of the idea that the history of knowledge and the history of human relationships that develop during the acquisition of this knowledge are two sides of scientific development.

A characteristic feature of modern scientific knowledge is the variety of concepts and approaches that are alternative to the positivist tradition. The totality of concepts in scientific knowledge in its philosophical perspective, which arose as a critical reaction to the neo-positivist program of empirical justification of science, is defined by the General concept of "postpositivism".

So, modern scientific knowledge shows strong links with philosophy. Scientists of the past considered empirical data as an absolutely reliable Foundation of science, formed as a result of direct perception of reality. However, at the present stage of development of scientific knowledge, it is clear that empirical knowledge always includes certain theoretical positions. This vision allows you to get accurate data, objective knowledge.

\section{BIBLIOGRAPHY}

1. Социологический энциклопедический словарь / ред.-координатор Г.В. Осипов. Москва : ИНФРА М-НОРМА, 1998. 488 с.

2. Научное знание: основы. URL : http:// 4brain.ru〉blog/научное-знание-основы.

3. Спенсер Г. Опыты научные, политические и философские. Минск : Современный литератор, 1999. $1408 \mathrm{c}$.

4. Філософський словник соціальних термінів / під заг. ред. В.П. Андрущенка. Харків : «Корвін», 2002. 672 с.

5. Всемирная энциклопедия: Философия / главн. науч. ред. и сост. А.А. Грицанов. Москва : АСТ, Минск: Харвест, Современный литератор, 2001. 1312 с.

6. Гельмгольц Г. Учение о слуховых ощущениях как физиологическая основа для теории музыки. Москва : URSS, 2011. 594 с.

7. Конт О. Дух позитивной философии. Ростов на Дону : «Феникс», 2003. 256 с.

8. Дюгем П. Физическая теория. Ее цель и строение. Москва : КомКнига, 2007. 328 с.

9. Карнап Р. Философские основания физики. Введение в философию науки. Москва : Прогресс, 1971.390 c.

10. Merton, Robert K. Sociology of Science: Theoretical and Empirical Investigations. Edited by Norman W. Storer. Chicago : University of Chicago Press, 1973. 606 p. 


\section{REFERENCES}

1. Sociologicheskij enciklopedicheskij slovar / red.-koordinator G.V.Osipov. Moskva: INFRA M-NORMA, 1998. $488 \mathrm{~s}$.

2. Nauchnoe znanie: osnovy. URL: http:// 4brain.ru>blog/nauchnoe-znanie-osnovy.

3. Spenser G. Opyty nauchnye, politicheskie i filosofskie. Minsk: Sovremennyj literator, 1999. $1408 \mathrm{~s}$.

4. Filosofskyi slovnyk sotsialnykh terminiv/ pid zah. red. V.P.Andrushchenka. Kharkiv: «Korvin», 2002. $672 \mathrm{~s}$.

5. Vsemirnaya enciklopediya: Filosofiya / glavn. nauch. red. i sost. A.A.Gricanov. Moskva: AST, Minsk: Harvest, Sovremennyj literator, 2001. 1312 s.

6. Gelmgolc G. Uchenie o sluhovyh oshusheniyah kak fiziologicheskaya osnova dlya teorii muzyki. Moskva: URSS, 2011. 594 s.

7. Kont O. Duh pozitivnoj filosofii. Rostov na Donu: «Feniks», 2003. $256 \mathrm{s.}$

8. Dyugem P. Fizicheskaya teoriya. Ee cel i stroenie. Moskva: KomKniga, 2007. 328 s.

9. Karnap R. Filosofskie osnovaniya fiziki. Vvedenie v filosofiyu nauki. Moskva: Progress, 1971. $390 \mathrm{~s}$.

10. Merton, Robert K. Sociology of Science: Theoretical and Empirical Investigations. Edited by Norman W. Storer. Chicago: University of Chicago Press, 1973. 606 p.

Борінштейн Свген Руславович

доктор філософських наук, професор,

завідувач кафедри філософії, соціології

та менеджменту соціокультурної діяльності

Державного закладу «Південноукраїнський національний педагогічний

університет імені К. Д. Ушинського»

вул. Старопортофранківська, 26, м. Одеса, Україна

Конах Микола Семенович

доктор філософських наук, професор,

викладач

Кам'янського медичного коледжу

вул. Медична, 7, м. Кам’янське, Дніпропетровська обл., Україна

\section{СУТНІСТЬ ТА ГЕНЕЗА НАУКОВОГО ЗНАННЯ: ФІЛОСОФСЬКА ПРОБЛЕМАТИКА}

У статті досліджується сутність та тенеза наукового знання з точки зору філософії. Аналізується роль діяльності в науковому пізнанні. При цььому наука визначається як сфера людської духовної діяльності, спрямованої на здобуття, обтрунтування та систематизаиію інтерсуб'єктивного знання про світ. Робиться історичний екскурс у розвиток науки. Йдеться про наукове знання, яке включає: закономірності науково-пізнавальної діяльності, головні принциии науки; особливості виникнення та історичного розвитку науки; специфіку існування науки як соціального інституту; структуру, динаміку, рівні та форми наукового знання; засоби і методи досягнення изього знання; значення і перспективи науки в сучасному світі. Автори розглядають особливості сучасного наукового знання, під яким розуміють кремезну за інформаційною ємністю і своїм розмірам надскладну гнучку структуру, що складається з різних наукових дисииплін, областей знання, рівнів, видів і форм наукового знання, які трунтуються на науковій діяльності. Відмічаються основні, з точки зору авторів, філософсько-методологічни підходи до визначення науки, а саме: логіко-епістемологічний підхід; позитивістський підхід; сочіологічний та культурологічний підходи.

У системі наукового знання особливе значення має наукове мислення. На думку авторів, наукове мислення є одним із способів пізнання реальності, що існує паралельно з іншими (повсякденним, художньо-образним) і не може витіснити їх. Різні способи мислення не просто співіснують, а взаємодіють один з одним, ведуть постійний діалог і можуть змінюватися внаслідок такого діалогу. Однак на кожному етапі історичного розвитку науки ми маємо справу з певним, визначеним науковим знанням, щзо створює засади для пошуку нового знання. 
Тому наукове знання охоплює: закономірності науково-пізнавальної діяльності, головні принциии науки; особливості виникнення та історичного розвитку науки; специфіку існування науки як соиіального інституту; структуру, динаміку, рівні та форми наукового знання; засоби і методи досягнення изьго знання; значення і перспективи науки в сучасному світі.

Для авторів є принщиповим розрізнення епістемології, яка аналізує місце знання в сучасній дійсності, та гносеології, щзо вивчає пізнавальний процес у цілому. Автори розглядають важливу роль об' єктивного знання, яке може дати, з їхньої точки зору, тільки системне філософське світобачення.

Ключові слова: наука, знання, наукове знання, сучасне наукове знання, повсякденне знання, епістемологія, гносеологія, позитивізм. 